Archived version from NCDOCKS Institutional Repository http://libres.uncg.edu/ir/asu/

Williams, M., \& Holcomb, J. (2001). Racial disparity and death sentences in Ohio. Journal of Criminal Justice, 29, 207-218. ISSN: 0047-2352

\title{
Racial disparity and death sentences in Ohio
} Marian R. Williams, Jefferson E. Holcomb

\begin{abstract}
The use of the death penalty has resulted in a number of studies attempting to determine if its application is consistent with the guidelines established by the United States Supreme Court. In particular, many studies have assessed whether there are racial disparities in the imposition of death sentences. This study examined the imposition of death sentences in Ohio, a state largely ignored by previous research and that, until 1999, had not executed an inmate since 1963. Drawing from previous studies that have examined the issue in other states, this study assessed the likelihood that a particular homicide would result in a death sentence, controlling for race of defendant and victim and other relevant factors. Results indicated both legal and extralegal factors (including race of victim) were significant predictors of a death sentence, supporting many previous studies that concluded that race plays a role in the imposition of the death penalty.
\end{abstract}

\section{Introduction}

On February 19, 1999, Ohio executed its first prisoner since 1963. With the country's sixth largest condemned population at 192 prisoners on death row (Death Row, USA, 1999), this will only add to the trend of increasing death sentences and executions (Snell, 1997). The present study was an examination of racial and case characteristics of those sentenced to death in Ohio. In particular, it was designed to determine if racial disparity existed in the imposition of death sentences. The methodology utilized follows that of several studies designed to examine similar issues in other states (e.g., Gross \& Mauro, 1989; Radelet \& Pierce, 1991). The replication of these studies seemed appropriate because neither of these studies examined Ohio and research into Ohio's capital punishment process is scarce compared to that of other jurisdictions (see General Accounting Office (GAO), 1996; Kleck, 1981).

\section{Historical background}

Capital punishment has existed in the State of Ohio since its territorial days, though it has been used for a very limited number of offenses (Bridge \& Mosure, 1961). As early 
as 1815, Ohio distinguished between first- and second-degree murder and limited capital offenses to first-degree murder and treason (Bridge \& Mosure, 1961). In 1824, the state legislature dropped treason as a capital offense, and first-degree murder became the sole capital crime in the state of Ohio (Bridge \& Mosure, 1961). Executions were originally carried out by local officials in the individual jurisdictions, but in 1885 changes in law required that all executions occur at the state penitentiary (Ohio Department of Rehabilitation and Correction (ODRC), 1999). In 1896 state law prescribed electrocution as the method of execution, which remained unchanged until a 1993 law gave condemned inmates the option of lethal injection (Leonard, 1993; ODRC, 1999). Historically, Ohio's criminal law has provided juries (or optional three-judge panels) with the discretion to sentence a defendant convicted of a capital crime to either life imprisonment or death (Bridge \& Mosure, 1961). Juries were given the option of finding a first-degree murder defendant guilty "with mercy," resulting in an automatic life sentence, or guilty without mercy in which the defendant was automatically sentenced to death. In 1972, the Supreme Court in Furman v. Georgia (408 U.S. 238, 1972) found the death penalty as then carried out to be unconstitutional (for more detailed discussion of the court's ruling see Bowers \& Pierce, 1984; Steiker \& Steiker, 1998). Ohio passed new capital statues in 1974 (Bowers \& Pierce, 1984) but these were found to be unconstitutional in Lockett v. Ohio $(438$ U.S. 586,1978$)$ largely because of limitations on the jury's ability to consider mitigating evidence proffered by the defendant (e.g., see Haney, 1998). Following Lockett v. Ohio (586), Ohio passed new death penalty statutes in $1981^{1}$ that have withstood constitutional review, ${ }^{2}$ and in 1999 Ohio executed its first prisoner since 1963, bringing the total number of persons executed in the state since 1885 to 345 (Johnson, 1999). Under the 1981 statutes, there must be a specific finding of the presence of at least one statutorily defined aggravating circumstance beyond a reasonable doubt before a defendant may be eligible for a death sentence (O.R.C. 2929.022, 1999). Defendants may choose to have the determination of the existence of aggravating circumstance at trial or in a separate hearing during the sentencing phase (O.R.C. 2929.03, 1999). Following the Court's ruling in Lockett v. Ohio (586), Ohio's current statutes require that defendants be given "great latitude in the presentation of evidence" of mitigating factors (O.R.C. 2929.03 [D][1], 1999). Aggravating circumstances are to be weighed against mitigating factors in the determination of sentence. If aggravating circumstances do not sufficiently outweigh mitigating factors, defendants are to receive a sentence other than death (O.R.C. 2929.03, 1999).

An essential element of the Court's ruling in Furman v. Georgia (238) was the apparent arbitrariness with which death sentences were imposed (see Bowers \& Pierce, 1984). According to Bowers and Pierce (1984), arbitrariness in sentencing manifests itself in several ways, including capriciousness, blatant discrimination, and sentencing disparities. Baldus, Woodworth, and Pulaski (1990) conceptualize the various types of arbitrary sentencing practices in a similar manner. Arbitrariness may exist either in individual cases or characterize the sentencing process of a particular jurisdiction (Baldus et al., 1990). For Baldus et al. (1990), the important consideration is the degree to which death sentences occur in a random fashion with either no legally relevant distinctions between cases that receive different sentences or the likelihood that legally 
impermissible factors (such as race of the defendant or victim) influence sentencing decisions. ${ }^{3}$ Factors that are not directly related to the offender's culpability violate the retributive sense of justice that scholars argue is key to the Court's ruling in Furman v. Georgia (238) and subsequent cases (Bowers \& Pierce, 1984; Steiker \& Steiker, 1998). Therefore, findings of racial disparities in the application of the death penalty suggest that arbitrariness continues to exist in post-Gregg v. Georgia (428 U.S. 153, 1976) statutes despite the Court's optimism. The authors have chosen to speak of sentencing disparities rather than discrimination to avoid assuming purposeful intent in particular cases. This usage is consistent with Baldus et al. (1990, p. 15), who noted that while aggregate level studies (such as the current one) can present evidence suggesting an influence of racial considerations in the decision-making process of a particular jurisdiction, "statistical evidence sheds no light on the degree to which the decisions adversely affecting the minority group were the product of a conscious purpose as opposed to a nonconscious bias." This study was an attempt to add to the body of literature investigating the characteristics of capital sentencing outcomes in various jurisdictions.

\section{Literature review}

Research into the characteristics of those sentenced to death, in particular, those designed to note possible bias or discrimination in the application of the death penalty, is not a new phenomenon (e.g., see Garfinkel, 1949; Wolfgang, Kelly, \& Nolde, 1962). Following the Supreme Court's rulings in Gregg v. Georgia (153) ${ }^{4}$ and McCleskey v. Kemp (478 U.S. 1019, 1987), ${ }^{5}$ an outpouring of social science research has been conducted to test the validity of the Court's optimism in the states' ability to develop capital statutes that would limit arbitrariness and heighten the reliability of capital sentences (e.g., Baldus et al., 1990; Gross \& Mauro, 1989; Radelet \& Pierce, 1991; Vito $\&$ Keil, 1988). The literature has grown to such an extent that several evaluations of the quality and findings of these studies have been written.

Kleck (1981) reviewed empirical studies of the relationship between legal and extralegal characteristics of homicides and execution rates prior to the Gregg v. Georgia (153) decision. Another widely cited review of the literature on race and capital punishment is the General Accounting Office's (GAO) (1996) study examining original empirical studies of capital punishment conducted with post- Furman v. Georgia (238) data. Except for cases of rape in the South where the defendant was Black and the victim White, Kleck (1981) found little evidence of race of defendant disparity among those receiving death sentences in the studies he examined. In contrast, the GAO (1996) study reported that more than half of the studies it reviewed found a race of defendant disparity and, in three-fourths of these; Blacks were more likely to be sentenced to death than Whites. Both the Kleck (1981) and GAO (1996) evaluations found substantial evidence for a race of victim effect. The finding that homicides with a White victim were more likely to result in the imposition of a death sentence than homicides with a Black victim was consistent across a variety of studies examining different time frames and jurisdictions. Specifically, the GAO (1996) report found in 82 percent of the studies that the race of the victim influenced the likelihood that a defendant would be 
either formally charged with a capital crime or sentenced to death and that these findings were consistent even after controlling for legally relevant variables.

For the purposes of this study, it was most productive to focus on reviewing those studies that were directly related to the present project in either methodology or the jurisdiction under study. Relatively few studies have been conducted that examined the issue of race and capital punishment in the state of Ohio. The earliest research of the relationship between race and death sentences in Ohio appears to be a legislative staff report conducted by Bridge and Mosure (1961). This study was primarily an overview of capital punishment in Ohio (1950-1959) with an emphasis on the issue of deterrence and therefore did not examine racial disparities in detail. The authors noted that it did not appear that Blacks were more likely to receive death sentences than Whites (Bridge \& Mosure, 1961). This claim must be approached with some caution as their only measure of racial disparity was the percentage of Whites (62.7 percent) and Blacks (37.3 percent) on Ohio's death row (Bridge \& Mosure, 1961). There was no examination of various offender-victim race combinations and no comparison of prisoners sentenced to death with those arrested, indicted, or convicted of noncapital murders. An interesting finding was that Whites were more than three times as likely to have their death sentences commuted than Blacks (Bridge \& Mosure, 1961; for studies with similar findings see Magnum, 1940; VanDiver, 1993; Wolfgang et al., 1962).

Bowers and Pierce (1984) examined the consequences of post-Furman v. Georgia (238) statutes in Florida, Georgia, Texas, and Ohio to test whether such structures had the desired effect of eliminating discrimination and arbitrariness in the imposition of capital sentences. Specifically, they collected Supplemental Homicide Report (SHR) data for the dates subsequent to the passage of the first post-Furman v. Georgia (238) statute in each jurisdiction. The Ohio data therefore consisted of homicides between November 1, 1974 and December 31, 1977. The SHR data were matched to specific cases in Florida, Texas, and Georgia that were sentenced to death and for those under a sentence of death in Ohio (Bowers \& Pierce, 1984). The authors found that in each state the overall probability of receiving a death sentence or, being on death row in Ohio, was substantially greater for Blacks and those who killed Whites (Bowers \& Pierce, 1984). In Ohio, the racial disparity within offender-victim racial combinations was even more pronounced. Blacks who killed Whites had an overall probability of ending up on death row five times that of Whites who killed Whites and almost fifteen times that of Black offenders with Black victims (Bowers \& Pierce, 1984). Since the Lockett v. Ohio (586) decision invalidated Ohio's death penalty, the authors chose to exclude Ohio from further analysis in their study. Therefore, it was impossible to comment on the relationship between other legal and extralegal factors and the racial composition of Ohio's death row from their study. For Florida, Georgia, and Texas, the study controlled for felony circumstances, intrastate regional differences, and multistage decisional outcomes such as indictments, conviction, and death sentencing. The authors found a consistent pattern of race of victim disparities in the overall probability of receiving a death sentence. Specifically, homicides with White victims had the highest probability of resulting in a death sentence (Bowers \& Pierce, 1984). Furthermore, in nearly all of their analyses, homicides where Black suspects killed Whites had the highest overall 
probability of resulting in a death sentence and homicides where Blacks killed Blacks had the lowest (Bowers \& Pierce, 1984).

Methodologically, the present study followed the work of Gross and Mauro (1989) and several studies that replicated that work in other jurisdictions (e.g., Radelet \& Pierce, 1991; Sorensen \& Wallace, 1995). Utilizing SHR data for homicides between 1976 and 1980, Gross and Mauro cross-referenced information from the SHR with data from the NAACP's Legal Defense Fund to identify specific cases resulting in death in several states (Gross \& Mauro, 1989). For each jurisdiction the authors examined a number of legal and extralegal variables and differences between those homicides that resulted in a death sentence and those that did not. In the three largest jurisdictions of Georgia, Florida, and Illinois, Gross and Mauro found that the death penalty was more likely to be imposed on individuals convicted of killing Whites and that Blacks convicted of killing Whites were more likely to be sentenced to death than Whites who kill Whites. While the authors did not find a race of defendant racial disparity among those sentenced to death, logistic regression revealed that the killing of a White victim greatly increased the odds of receiving a death sentence (Gross \& Mauro, 1989). These findings were consistent in Virginia and the four smaller jurisdictions of Arkansas, Mississippi, Nebraska, and Oklahoma: White victim homicides were more likely to result in death sentences than Black victim homicides, controlling for several legally relevant factors (Gross \& Mauro, 1989).

Radelet and Pierce (1991) sought to replicate Gross and Mauro's (1989) work in Florida for homicides occurring between 1976 and 1987. Matching SHR data and case files for those homicides resulting in a death sentence, Radelet and Pierce examined the relationship between the racial characteristics of the offender and victim and whether a death sentence was imposed. After controlling for legally relevant aggravating factors, the authors found a consistent race of victim disparity among those sentenced to death. Those convicted of killing Whites were over five times as likely to receive a death sentence compared to those whose victim was Black (5.9 and 1.0 percent, respectively) (Radelet \& Pierce, 1991). Among those suspected of killing Whites, Blacks (12.6 percent) were nearly three times as likely to receive a death sentence as Whites (4.9 percent) (Radelet \& Pierce, 1991). Furthermore, Blacks who killed Whites were almost four times as likely to receive a death sentence as Whites who killed Blacks (12.6 and 3.4 percent, respectively) (Radelet \& Pierce, 1991). Incorporating legally aggravating factors as well as extralegal variables, Radelet and Pierce ran a logistic regression equation model and found that in addition to predicted legally relevant variables (such as felony circumstances and multiple victims), both race and sex of the victim were significantly related to case outcome. Specifically, those cases with a White victim (3.42 odds ratio) had a significantly higher odds of resulting in a death sentence than those cases with a Black victim.

Sorensen and Wallace (1995) examined SHR data and trial court reports for homicides in Missouri between 1977 and 1991 . The authors looked at the relationship between legal and extralegal factors such as race of offender and victim to case outcomes at several decision points in the adjudication process. In reviewing comparisons of case 
outcomes and racial characteristics of offenders and victims across the capital punishment process, Sorensen and Wallace found mixed results. Generally, White offenders and those cases with White victims were treated more severely than Black offenders or victims (Sorensen \& Wallace, 1995). An interesting finding was that Blacks who killed Whites were much more likely to be convicted of capital murder than Whites convicted of killing Whites, and substantially more likely to be convicted of capital murder than Whites who killed Blacks (20.5 to 6.7 percent, respectively) (Sorensen \& Wallace, 1995). Logistic regression models for outcomes at each decision point were calculated with aggravating factors and extralegal factors. The authors found no consistent evidence of race of defendant disparity, but results indicated that homicide cases (2.6 odds ratio) and felony murder cases (3.3 odds ratio) with White victims were more likely to result in a capital conviction than those with Black victims.

More recently, a study by Thomson (1997) examined racial and ethnic discrimination in death sentencing in Arizona. The author utilized the SHRs from 1982 to 1991, omitting homicide incidents that did not have complete offender and victim data. With a final sample of 2028 homicide incidents, the author cross-referenced the data with information from the NAACP Legal Defense Fund. Results indicated that White offenders were more than 1.5 times as likely to receive a death sentence than minority offenders. Consistent with the findings of the above studies, however, Thomson found that offenders who killed White victims were more than twice as likely to receive a death sentence than offenders who killed minority victims.

It appears from the above research and others (e.g., Baldus et al., 1990; Radelet, 1981) that race of defendant bias is not at as problematic as it once was (see Kleck, 1981). Race of victim disparities, however, continue to persist across various jurisdictions even while controlling for many of the exogenous variables and circumstances that previous researchers considered essential (Kleck, 1981). Evidence at various levels of the capital punishment process thus tends to support Kleck's (1981) proposition of "devalued" Black victims. The current study is designed to test whether such findings are consistent with juridical practices for homicides in Ohio.

\section{Methodology}

The current study attempted to provide an aggregate level examination of race and the use of the death penalty. This study should be considered a preliminary examination of a non-Southern state whose death sentencing practices have not been examined thoroughly. It was recognized that the preferred methodology would have been to follow individual cases throughout the sentencing process to examine the possibility of disparate outcomes at each decision-making point. This would have also enabled the researchers to collect more thorough information for each case and to avoid some of the validity problems posed by the SHR data (e.g., see Maxfield, 1989). Studies that analyze individual case files for homicides are extremely time-consuming and expensive (GAO, 1996) and few studies have provided such a detailed examination of this issue. Notable exceptions include the Baldus et al. (1990) study that was funded by several organizations and agencies including the U.S. Department of Justice and took several 
years to complete. A lack of resources precluded the present authors from engaging in such a study. What is unique about the current study was its focus on a non-Southern state with a large death row population.

\section{Data source}

The methods used for the current study were adapted from those used by Gross and Mauro (1989) ${ }^{6}$ and Radelet and Pierce (1991). Data concerning homicides in Ohio were taken from the SHR compiled by the FBI. Although some researchers (e.g., Maxfield, 1989) have indicated potential problems with SHR data, a number of studies have utilized SHR reports in death penalty research, including those investigating issues of deterrence (e.g., Bailey, 1998; Cochran, Chamlin, \& Seth, 1994; Peterson \& Bailey, 1991) and racial disparities in sentencing (e.g., Radelet \& Pierce, 1991; Sorensen \& Wallace, 1995; Thomson, 1997). One potential problem with SHR data, according to Maxfield (1989), is missing information routinely found in the data. Because SHR data reflect preliminary information (in many cases before an offender is apprehended), many of the characteristics of the offense/offender/victim are not immediately known, and are therefore missing. To account for this, many studies (e.g., Gross \& Mauro, 1989; Radelet \& Pierce, 1991; Thomson, 1997) excluded the missing data from the analysis. This was reasonable because in many cases, the offender was not identified and therefore was ineligible for sentencing. According to Riedel and Rinehart (1996), missing data occur across a variety of murders and do not represent a systematic exclusion of particular variables.

Another potential problem with SHR data is that information may be underreported or overreported. For example, Peterson and Bailey (1991, p. 373) found that SHR data may report a lower number of homicide incidents than the Uniform Crime Reports (UCR) because not all police departments participate in the SHR program. Despite this, their study found that UCR and SHR data were highly correlated $(r=.89)$ for variables found in both the UCR and SHR (offense/offender/victim data), suggesting that SHR data "provide a reasonable indicator of ... homicide patterns ... . over the period analyzed. Peterson and Bailey (1991) also used a control variable that took into account the difference between the UCR and the SHR. Conducting analyses both with and without the control variable, the authors found similar results (1991). The present study found 252 more homicide incidents in the SHR data when compared to the UCR. According to Maxfield (1989), this may be a reflection of reclassification of incidents from murder or nonnegligent manslaughter to negligent manslaughter in the UCR after more information became known about the incident. Despite this, when analyzed with the UCR data for the same period for offender/offense/victim data, a significant correlation between the two $(r=.96)$ was found.

The SHR data used for the current study were 1981 (the year Ohio reintroduced the death penalty into law) through 1994. The SHR data contained information regarding incidents of murder and negligent and nonnegligent manslaughter. The SHR data were coded in such a way to distinguish between "murder and nonnegligent manslaughter" and "negligent manslaughter." Cases of negligent manslaughter were omitted from the 
analyses because the criminal nature of such acts is often in dispute and penalties are considerably less than those for other homicides. The SHR does not distinguish between murder and nonnegligent manslaughter; therefore, cases of nonnegligent manslaughter (which are not death eligible) had to be included in the present analysis. To account for this, the present study included analyses for the entire sample and analyses of a subsample limited to those cases with felony circumstances, which is an aggravating circumstance under Ohio law. The subsample was used to determine if there were differences between the sample as a whole and those cases with a greater likelihood of receiving a death sentence.

The SHR data included information on several variables for each homicide: offender's age, gender, race; victim's age, gender, race; circumstances surrounding the offense; weapon used; relationship between offender and victim; and county where the crime took place. As indicated above, the SHR contained missing data. Peterson and Bailey (1991) found that the percentage of missing data cases in their study was between 9 and 25 percent, depending on the variable. In the present study, victim data were missing in less than 1 percent of the cases, while offender data were missing in 24 percent of the cases. This is not surprising for the SHR since homicide victims are more easily identified than victims of other crimes. Relationship and felony circumstance data were missing from 25 percent of the cases, and weapon data were missing in 3 percent of the cases. Those cases with missing data were excluded from analyses examining the particular variable from which data were missing. In order to determine if the missing data represented a systematic bias in the results, a dummy variable was created for each variable that had missing data for more than 5 percent of the cases (offender gender, race, age; relationship; felony circumstances) and correlation statistics between the dummy variables and the other variables in the analysis were conducted to test for significance. Results indicated that systematic bias did not result from exclusion of the missing data.

Data about homicides resulting in a death sentence were gathered from the Office of the Ohio Public Defender. Additional information was obtained from the Office of the Ohio Attorney General and the Ohio Department of Rehabilitation and Correction. Death sentence data included the same information as that found in the SHR.

\section{Sample}

The SHR information and the death penalty information were merged into one database. To achieve this, each homicide that resulted in a death sentence (drawn from case file information obtained from the Office of the Ohio Public Defender) was identified in the SHR data. This method was adopted from Gross and Mauro (1989) and Sorensen and Wallace (1995) - matching each death penalty case with a homicide including identical information. The most important variables in the matching process, similar to Sorensen and Wallace, were date of the offense and the race, sex, and age of the offender and victim. All but fifty-five of the death sentence cases were matched in this way. For these remaining cases, offender data were missing in the SHR, but other relevant data (victim, weapon, relationship, date of offense, circumstance data) were 
available. The authors were able to identify those death sentence cases in the SHR with missing offender data by matching relevant information in the SHR (victim data, date of offense, weapon, relationship) with information found in offender's case file. The result was that the authors were confident that they had correctly identified each death sentence case in the SHR.

Information was coded regarding the number of death sentences imposed, not the number of individuals who received a death sentence. For instance, although only 185 individual death row inmates were used in this study, the number of death sentences imposed was 271 , reflecting those inmates who killed multiple victims and those homicides with multiple offenders. This was done to account for those offenders who received multiple death sentences. All death sentences were considered, including those that were eventually overturned and acquitted, overturned and resentenced to a lesser sentence, and overturned and resentenced to death. The coding of the death sentences in such a way was different from Gross and Mauro (1989), who used homicides as the unit of analysis and treated homicides with multiple victims (and multiple death sentences) as one incident. ${ }^{7}$ This coding is also different from Radelet and Pierce (1991), who only counted multiple victims if death sentences occurred in separate trials, and did not include those offenders who were eventually resentenced. Sorensen and Wallace (1995) used the offender as a unit of analysis, examining whether or not an offender received a death sentence for any homicide. The present analysis was offense-based, not offender based. This allowed the authors to examine the characteristics of specific death sentences, and why these sentences resulted in death rather than life imprisonment or some other sentence.

The SHR death sentence database used in the analysis (1981-1994) consisted of 9393 cases. The usable sample, however, was necessarily limited by two factors. First, those cases in which there was no known information about the suspect were excluded from the analysis. Second, cases in which the offender was under the age of eighteen at the time of the offense were not included in the analysis since, under Ohio law, individuals under the age of eighteen are not eligible for the death penalty (Ohio Revised Code, $2929.023,1999)$. This left an available sample of 6441 cases of homicides committed by known suspects who were eighteen years of age or older at the time of the offense. While complete data were gathered for all cases that resulted in a death sentence, the sample size was further reduced due to missing data for other variables among SHR cases, resulting in a final sample of 5319 for the multivariate analyses. Therefore, some of the categories described in Table 1 had a slightly different sample size as the number of cases with usable data varied.

Variables

The variables used in the study consisted of one dependent variable, whether a death sentence was imposed, and multiple independent variables. Many SHR variables contained multiple values and therefore some of these variables were collapsed for the purpose of the current study. These variables are listed in Table 1. In order to determine whether race played a role in determining who received a death sentence, it was 
necessary to include the variables mentioned in Table 1 as any or all of the control variables could mitigate the effect of race on sentencing.

\section{Prior record}

Before addressing the results the authors believe it is important to discuss the omission of prior record as a control variable. While commentaries have been made about the importance of including information

Table 1

Variables in the analysis

\begin{tabular}{|c|c|c|}
\hline \multirow[t]{2}{*}{$\overline{\text { DEATH }}$} & Was a death sentence imposed? & $0=$ no $(n=6170)$ \\
\hline & $n=6441$ & $1=\operatorname{yes}(n=271)$ \\
\hline \multirow[t]{2}{*}{ VICSEX } & What is the victim's sex? & $0=$ female $(n=1750)$ \\
\hline & $n=6440$ & $1=$ male $(n=4690)$ \\
\hline \multirow[t]{2}{*}{ VICRACE ${ }^{a}$} & What is the victim's race? & $0=$ non-White $(n=3521)$ \\
\hline & $n=6432$ & $1=$ White $(n=2911)$ \\
\hline \multirow[t]{2}{*}{ OFFSEX } & What is the offender's sex? & $0=$ female $(n=974)$ \\
\hline & $n=6435$ & $1=$ male $(n=5461)$ \\
\hline \multirow{2}{*}{ OFFRACE $^{a}$} & What is the offender's race? & $0=$ non-White $(n=3860)$ \\
\hline & $n=6430$ & $1=$ White $(n=2570)$ \\
\hline \multirow[t]{2}{*}{ WEAPON $^{\mathrm{b}}$} & What type of weapon was used? & $0=\operatorname{gun}(n=3982)$ \\
\hline & $n=6311$ & $1=$ non-gun $(n=2329)$ \\
\hline \multirow[t]{2}{*}{ RELATION $^{c}$} & Was it a stranger homicide? & $0=$ no $(n=4784)$ \\
\hline & $n=6226$ & $1=$ yes $(n=1442)$ \\
\hline \multirow[t]{2}{*}{$\mathrm{CIRC}^{\mathrm{d}}$} & Did homicide involve other felony? & $0=$ no $(n=4595)$ \\
\hline & $n=5588$ & $1=\operatorname{yes}(n=993)$ \\
\hline \multirow[t]{2}{*}{ MULTVICT } & Was offense a multiple homicide? & $0=$ no $(n=5858)$ \\
\hline & $n=6441$ & $1=$ yes $(n=583)$ \\
\hline \multirow[t]{2}{*}{ URBAN } & Did homicide occur in urban area? & $0=$ no $(n=484)$ \\
\hline & $n=6441$ & $1=$ yes $(n=5957)$ \\
\hline \multirow[t]{2}{*}{ VICAGE } & Was victim twelve years old or younger? & $0=$ no $(n=6010)$ \\
\hline & $n=6420$ & $1=$ yes $(n=410)$ \\
\hline \multirow[t]{2}{*}{ OFFAGE } & Was offender over twenty-five? & $0=$ no $(n=2322)$ \\
\hline & $n=6441$ & $1=$ yes $(n=4119)$ \\
\hline
\end{tabular}

" SHR data coded race as "White, Black, Native American, Asian and Islander, and Other." For the current study, the race variable was collapsed, reflecting "White" (White, Native American, Asian and Islander) and "non-White" (Black). This did not affect the results of the analysis, since few Native Americans, Asians, and Islanders appeared as offenders or victims. It should be noted that Hispanics are coded as "White" in the SHR reports.

b SHR data coded weapon as one of 17 possible choices, ranging from five different types of guns to poisoning, asphyxiation, etc. The current study combined all guns into one value and all non-guns into another.

c SHR data coded relationship as one of 29 possible choices, ranging from various family members to friends, acquaintances, to strangers. The current study collapsed all values into the ones seen in the table.

${ }^{d}$ SHR data coded circumstances as one of 33 possible choices, ranging from various crimes committed during the course of the homicide to gang killing to lover's triangle, etc. All SHR values that involved a felony incident were collapsed into one value and all other values were treated as non-felony homicides.

on prior record in research on the imposition of death sentences and executions (e.g., Kleck, 1981), the authors feel that there are three arguments that mitigate such criticism. The first issue is a pragmatic one. Although researchers should always seek the most complete, reliable, and valid data available, the data on the prior record for the over 6000 cases were simply not available to the researchers. This left the authors in the position of choosing between continuing on an important topic in a jurisdiction where little research had been conducted or abandoning the project in fear of the obvious 
criticism. Believing that the methodology had at least facial validity, the former was chosen. Second, it was clear from prior research that race of the defendant was unlikely to be an independent predictor of whether one received a death sentence. The argument that those who kill Whites are more likely to have a serious prior record is questionable. Critics could contend that prior record has a significant role in who receives a death sentence in those jurisdictions where it is an aggravating factor, as in Ohio. Theoretically, this could mitigate racial disparities noted among the imposition of death sentences. If this were so, homicides with Black victims, who are most likely to be killed by Black offenders, should result in a substantial number of death sentences since Black offenders are more likely to have serious prior arrests than White offenders (Donzinger, 1996). The present study found just the opposite. Homicides with Black victims were less likely to result in a death sentence than those homicides with White victims. In particular, Blacks killed by other Blacks was consistently the racial combination least likely to result in a death sentence. Third and most importantly, previous research has actually shown that prior record has little impact on the race of victim disparity (Gross \& Mauro, 1989). As Gross and Mauro (1989) pointed out, the Baldus et al. (1990) study was the most comprehensive analysis ever conducted on racial disparities and the death penalty. Baldus et al. (1990) included over 200 variables in their analysis including serious prior record. Their finding that homicides in Georgia with White victims were 4.3 times more likely to end in a death sentence was not mitigated when prior record was controlled (Baldus et al., 1990). Furthermore, the findings of the Baldus et al. (1990) study in Georgia reflected a pattern and extent of racial disparities similar to that found in Gross and Mauro's (1989) examination of the same jurisdiction for roughly the same time periods. This study replicated the methods used in Gross and Mauro's (1989) study and the authors are encouraged by the degree of reliability those studies suggest for the current research.

\section{Results}

Initial analyses were conducted using the race of defendant and victim variables in order to measure the independent mitigating effects of these variables on the racedeath sentence relationship. As seen in previous studies, Table 2 shows that death sentences were rarely imposed, consisting of only 4 percent of total sentences. Although results show that White suspects were more likely than Black suspects to receive a death sentence ( 5 and 3 percent, respectively), further analysis revealed that those convicted of killing Whites were over twice as likely to receive a death sentence than those convicted of killing Blacks (6 and 2 percent, respectively). The authors further distinguished offender-victim racial combinations rather than merely looking at race of victim or race of defendant. As Bowers and Pierce (1984) noted, differential treatment of both offenders and victims are likely obscured when examined at the aggregate level without making such distinctions (Bowers \& Pierce, 1984). It originally appeared that White suspect homicides were treated more severely than homicides with Black suspects. After looking at specific victim-offender racial combinations, however, 
Table 2

Percentage of death sentences imposed, by racial character-

istics

\begin{tabular}{lc}
\hline Death sentence imposed & 4 percent $(271 / 6441)$ \\
White suspect & 5 percent $(138 / 2569)$ \\
Black suspect & 3 percent $(133 / 3854)$ \\
White victim & 6 percent $(186 / 2902)$ \\
Black victim & 2 percent $(85 / 3521)$ \\
Black kills White & 11 percent $(56 / 517)$ \\
White kills White & 5 percent $(130 / 2385)$ \\
Black kills Black & 2 percent $(77 / 3337)$ \\
White kills Black & 4 percent $(8 / 184)$ \\
\hline
\end{tabular}

this pattern was partially reversed. The percentage of homicides with Black offenders and White victims that resulted in a death sentence (11 percent) was twice that of homicides with White offenders and victims (5 percent) and nearly three times greater than the percentage of homicides where Whites killed Blacks (4 percent). Furthermore, Blacks who killed Whites were five times more likely to receive a death sentence than Blacks who killed Blacks (11 and 2 percent, respectively). This was interesting because although Blacks killing Blacks comprised the largest group of homicides, they were the racial grouping least likely to receive a death sentence. These findings were consistent with the pattern found by Gross and Mauro (1989) and Radelet and Pierce (1991).

As Radelet and Pierce (1991) stated, simple bivariate analyses on racial composition do not present a complete picture of racial disparities in sentencing. Because there may be qualitative reasons for the racial differences in death penalty sentencing, the use of control variables is important. For the sake of economy and focus, the present authors chose not to report each bivariate analysis controlling for the previously mentioned variables. ${ }^{8}$

In addition to the above analysis, logistic regression was performed to assess racial disparities controlling for all of the legal and extralegal variables within a single model. Logistic regression allows the researcher to incorporate possible predictor variables and assess their relative importance to the likelihood of receiving a particular outcome (see Baldus et al., 1990; Sorensen \& Wallace, 1995). Such an analysis had the potential to inform the researcher of factors that may partially explain the relationship found in the bivariate analyses. Table 3 reports the results of the logistic regression analysis with all of the above noted independent and control variables. Several of the legal and extralegal predictor variables were significant at the given alpha level. The most significant predictor was felony circumstances, which was not surprising as the presence of felony circumstances is an aggravating factor in the determination of a death sentence in the state of Ohio. ${ }^{9}$ Those homicides involving felony circumstances were more likely ( 35.4 odds ratio) to result in a death sentence than homicides involving nonfelony circumstances. Homicides with older offenders (twenty-five and older) were more likely (2.2 odds ratio) to receive a death sentence than those with younger offenders. ${ }^{10}$ This was not an unusual finding as youth of the offender is a mitigating circumstance under Ohio law. While not an aggravating circumstance under Ohio law, many researchers (e.g., Gross \& Mauro, 1989) treated homicides with multiple victims 
as a relevant aggravating factor. Similar to other research findings (e.g., Radelet \& Pierce, 1991), those who killed

Table 3

Logistic regression model for death sentences

\begin{tabular}{lrrr}
\hline Variable & $B$ & Standard error & Odds ratio \\
\hline VICSEX & 0.8518 & 0.1599 & $2.3438^{* *}$ \\
VICRACE & 0.5082 & 0.2030 & $1.6623^{* *}$ \\
OFFSEX & 0.9464 & 0.4267 & $2.5764^{*}$ \\
OFFRACE & 0.0701 & 0.1915 & 1.0726 \\
WEAPON & 0.0312 & 0.1652 & 1.0317 \\
RELATION & 0.5861 & 0.1764 & $1.7969^{* *}$ \\
CIRC & 3.5404 & 0.2149 & $35.4811^{* *}$ \\
MULTVICT & 1.9075 & 0.1744 & $6.7364^{* *}$ \\
URBAN & -0.3626 & 0.2505 & 0.6958 \\
VICAGE & 0.3801 & 0.2971 & 1.4624 \\
OFFAGE & 0.7974 & 0.1638 & $2.2198^{* *}$ \\
CONSTANT & -12.8825 & $1.2860^{* *}$ & \\
MODEL CHI-SQUARE $=919.832^{* * *}$ & & & \\
\hline
\end{tabular}

$n=5319$.

$* P<.05$.

** $P<.01$.

multiple victims were significantly more likely to receive a death sentence than those who killed one victim (6.7 odds ratio).

Several extralegal variables were also found to increase the likelihood of receiving a death sentence. The results for these variables were similar in direction and in some cases in strength to those noted in Gross and Mauro (1989) and Radelet and Pierce (1991). Homicides with male offenders (2.6 odds ratio) and female victims (2.3 odds ratio) were significantly more likely to result in a death sentence than homicides with female offenders or male victims. The relationship of offender to the victim was also significant at the given alpha level as homicides involving strangers were more likely (1.8 odds ratio) to result in a death sentence than homicides involving nonstrangers.

The findings for the primary variables of interest, race of the offender and victim, were consistent with those of several of the previously noted studies (Gross \& Mauro, 1989; Radelet \& Pierce, 1991). Race of the defendant did not significantly affect the likelihood of receiving a death sentence after controlling for several aggravating and extralegal variables. This was not surprising as most post-Gregg v. Georgia (153) researchers (Baldus et al., 1990; Kleck, 1981; Radelet, 1981) acknowledged race of defendant discrimination in the imposition of death sentences has not been shown to be a strong predictor of receiving a death sentence when other relevant factors were considered. Similar to these studies, the present study found that a race of victim disparity, though not as strong as that reported in other (especially Southern) jurisdictions, does exist 
Table 4

Logistic regression model for homicides with felony circumstances

\begin{tabular}{lrlc}
\hline Variable & $B$ & Standard error & Odds ratio \\
\hline VICSEX & 0.9924 & 0.1676 & $2.6976^{* *}$ \\
VICRACE & 0.5606 & 0.2065 & $1.7517^{* *}$ \\
OFFSEX & 0.6534 & 0.4453 & 1.9220 \\
OFFRACE & 0.2080 & 0.1896 & 1.2314 \\
WEAPON & 0.0331 & 0.1727 & 1.0036 \\
RELATION & 0.2650 & 0.1735 & $1.3034^{* *}$ \\
MULTVICT & 1.7783 & 0.1817 & $5.9200^{* *}$ \\
URBAN & -0.8264 & 0.2533 & $2.2850^{* *}$ \\
VICAGE & 0.5355 & 0.3232 & 1.7083 \\
OFFAGE & 0.9996 & 0.1611 & $2.7171^{* *}$ \\
CONSTANT & -10.6109 & $1.3183^{* *}$ & \\
MODEL CHI-SQUARE $=256.238^{* *}$ & & & \\
\hline
\end{tabular}

$n=1112$.

$* * P<.01$.

in Ohio. Even while controlling for several relevant aggravating factors, homicides with White victims were more likely (1.6 odds ratio) to result in a death sentence than homicides with Black victims.

Since the previous analyses likely included many non-death eligible cases, the authors chose to conduct analyses on cases that were more likely to have been considered death eligible. Since felony circumstance is an aggravating factor under Ohio law (and the most significant variable in the analyses), it was used to differentiate those cases that were statistically more likely to result in a death sentence. The authors used this to statistically improve the chances of distinguishing death eligible cases from non-death eligible ones. ${ }^{11}$ In doing so, the sample size was reduced to reflect those cases with felony circumstances. The results in Table 4 indicate that, for potentially death-eligible cases, victim race was significant at the given alpha level. In particular, homicides involving White victims were more likely to result in a death sentence than homicides involving Black victims (1.75 odds ratio).

\section{Discussion}

The present findings were interesting for both their similarities to and differences with previous research. Generally, findings supported those of Gross and Mauro (1989) and Radelet and Pierce (1991). Regarding differences in findings, the present study did not find the degree of racial disparity noted in the above studies. Though it was clear that race of the victim increased the likelihood of a homicide resulting in a death sentence in Ohio, such odds were not as high as those found in the other studies. It was interesting that the degree of disparity found in Ohio most closely resembles that found in Illinois (see Gross \& Mauro, 1989). It is possible that racial disparities exist across regions but they are most pronounced in southern jurisdictions.

Regarding the bivariate analysis, the data indicated that homicides with White victims were more likely to result in a death sentence than homicides with Black victims. Furthermore, homicides where Blacks killed Whites was the group most likely to receive a death sentence. Homicides with Black victims, regardless of the race of the suspect, 
were typically the least likely to result in a death sentence. Logistic regression revealed, however, that race of the defendant was not an independent predictor of a death sentence. This suggests that some of the disparities found in the bivariate analyses were partially explained by other factors. Nevertheless, disparities were found for the race and gender of the victim and gender of the offender. Most related to the present purpose was the finding that even when controlling for several legally relevant factors, homicides with White victims were more likely to result in a death sentence than those with Black victims. These results remained when examining death-eligible cases only. Such results support the idea of a "devalued Black victim" (Kleck, 1981). It is also possible that because homicides with Black victims, in particular, Blacks killed by Blacks, are the most common type of homicide, decision-makers do not treat such cases as severely as more unusual ones. The finding of gender disparity for both the offender and victim, though perhaps not unexpected, suggests that it is not only racial factors that add to the arbitrariness of death sentences. While not as strong as those reported by previous research, these findings add support to a growing body of literature that points to racial and extralegal disparities, rather than overt discrimination, in the imposition of death sentences in America (Baldus et al., 1990; Bowers \& Pierce, 1984; Gross \& Mauro, 1989; Radelet, 1981; Sorensen \& Wallace,1995; Vito \& Keil, 1988).

Future research

There are several decision-making points in the adjudication process that could arguably account for the above disparities. Because this was an input-output model and did not differentiate specific decision-making outcomes, it is impossible to determine if these disparities were the result of prosecutorial or jury actions. (see Baldus, Woodworth, Zuckerman, Warner, \& Brofitt, 1998; Sorensen \& Wallace, 1995; Vito \& Keil, 1988 for studies that examine disparities at more than one outcome point). Any comments regarding the moment where present results were manifested would merely be unsubstantiated speculation. This weakness, however, points out the need for future research that can distinguish various decision-making outcomes and racial disparities. As such research would likely involve fewer and more identifiable cases, it should be possible to control for more factors, including prior record. Another subject of future research should be a review of Ohio appellate court rulings upon direct appeal. Although the Ohio courts have dismissed numerous racial disparity claims (see e.g., State v. Carter (72 Ohio St. 3d 545; 651 N.E. 2d 965 1995); State v. Dickerson (45 Ohio St. 3d 206; 543 N.E. 2d 1250, 1989); State v. Keene (81 Ohio St. 3d 646; 693 N.E. 2d 246, 1998); State v. Sowell (39 Ohio St. 3d 322; 530 N.E. 2d 1294, 1988); State v. Steffen (31 Ohio St. 3d 111; 509 N.E. 2d 383, 1987)), the present study found that disparity exists, suggesting that Ohio's capital punishment process needs further examination. The size of Ohio's death row and its recent renewal of executions only intensify the need for such research.

Acknowledgments 
The authors thank William R. King for comments and criticisms of several drafts of this work and Michael T. Glantz for his insight on various issues in capital punishment. The assistance of Brenda Jones at the Ohio Public Defender's Office in providing data on offenders sentenced to death in the State of Ohio was essential for this project.

Notes

1. Am. Sub. Senate Bill 1, effective October 19, 1981.

2. State v. Jenkins (15 Ohio St. 3d 164; 473 N.E. 2d 264, 1984) - found Ohio's capital punishment statute to be constitutional.

3. The issue of clearly distinguishing between arbitrariness, discrimination and sentencing disparities is often confused by various interpretations of Supreme Court rulings. For the present study, the authors follow the general distinctions suggested by works such as Baldus et al. (1990), Bowers and Pierce (1984), and Gross and Mauro (1989). Arbitrariness is thought to exist when no legally permissible factors distinguish different sentencing outcomes. Discrimination, being an affirmative rather than negative act, is considered the most blatantly unconstitutional form of arbitrariness (Bowers \& Pierce, 1984; Gross \& Mauro, 1989). In McCleskey v. Kemp (1019), however, the Supreme Court ruled that mere aggregate level evidence of arbitrariness was insufficient to determine that an outcome in a specific case was motivated by purposeful discrimination. Despite this ruling, researchers have continued to investigate aggregate based evidence of arbitrary sentencing practices in various jurisdictions (e.g., Radelet \& Pierce, 1991; Sorensen \& Wallace, 1995; Thomson, 1997).

4. Gregg v. Georgia (153) Đ Court ruled Georgia's capital punishment system was no longer unconstitutional.

5. McCleskey v. Kemp (1019) - Court found evidence of aggregate level disparity unconvincing and that a defendant must show discrimination in their individual cases.

6. It should be noted that Gross and Mauro studied the same jurisdiction as Baldus et al. (1990) and found similar results, despite using a different methodology.

7. For example, Gross and Mauro treated multiple homicides with at least one Black victim as a single "Blackvictim homicide," thereby ignoring the racial characteristics of other victims in the multiple homicide. The authors felt it was problematic to collapse multiple homicides into a "one defendant-one victim" category, as such a method could result in systematic bias in one direction or the other depending on how the such cases were coded. Even though there were few offenders with multiple race victims ( $\mathrm{N}$ offenders $=5$; total $\mathrm{N}$ of victims of those offenders $=16$ ), excluding such cases from the analysis seemed inappropriate as well. Considering the importance of race of victim in previous research findings, the authors choose to be as inclusive as possible for this variable. Using individual death sentences (rather than offenders) allowed the authors to better examine the impact of the race of victim. 
8. Readers interested in examining the tables are encouraged to contact the authors. For a majority of such analyses, a pattern similar to that noted in the text was found. The only variables with any mitigating effect on such disparities were felony circumstances and relationship of offender to victim, where the percentage of homicides with specific racial combinations resulting in a death sentence was more equitable. Nevertheless, even within these combinations, White-victim homicides were still the most likely to result in a death sentence.

9. For a list of aggravating and mitigating circumstances, see Ohio Revised Code, 2929.04 (1999).

10. The use of 25 as the cutoff point for "youth of the offender" is consistent with that used by Sorensen and Wallace (1995).

11. The authors recognize the limitations of such an approach, and that merely having felony circumstances does not clearly distinguish death eligible cases from nondeath eligible cases. Given the limitations of the data, however, it seemed the best method to evaluate potential systematic bias.

References

Bailey, W. (1998). Deterrence, brutalization, and the death penalty: another examination of Oklahoma's return to capital punishment. Criminology, 36, 711 - 734.

Baldus, D. C., Woodworth, G., \& Pulaski, C. A. Jr. (1990). Equal justice and the death penalty: a legal and empirical analysis. Boston: Northeastern Univ. Press.

Baldus, D. C., Woodworth, G., Zuckerman, D., Warner, N. A., \& Brofitt, B. (1998). Racial discrimination and the death penalty in the post-Furman era: an empirical and legal overview, with recent findings from Philadelphia. Cornell Law Review, 83, 1638-1770 (retrieved from LEXIS-NEXIS on-line database on 6/8/99).

Bowers, W. J., \& Pierce, G. L. (1984). Arbitrariness and discrimination under post Furman capital statutes. In: W. J. Bowers, G. L. Pierce, J. F. McDevitt (Eds.), Legal homicide (193- 269). Boston: Northeastern Univ. Press. Bridge, F. M., \& Mosure, J. (1961). Capital punishment. Ohio Legislative Service Commission, staff research report no. 46. Columbus: F. J. Heer Printing.

Cochran, J., Chamlin, M., \& Seth, M. (1994). Deterrence or brutalization? An impact assessment of Oklahoma's return to capital punishment. Criminology, 32, 107-134.

Death Row, USA (1999). Publication of NAACP Legal Defense Fund. Data retrieved from Death Penalty Information Center web page hwww.essential.org/dpici on 7/11/99. 
Donzinger, S. R. (Ed.). (1996). The real war on crime: the report of the National Criminal Justice Commission. New York: HarperPerennial.

Garfinkel, H. (1949). Research note on inter- and intra-racial homicides. Social Forces, 27, 369.

General Accounting Office (1996). Death penalty sentencing: research indicates pattern of racial disparities. In: H. A. Bedau (Ed.), The death penalty in America: current controversies (pp. 268 - 272). New York: Oxford Univ. Press.

Gross, S., \& Mauro, R. (1989). Death and discrimination: racial disparities in capital sentencing. Boston: Northeastern Univ. Press.

Haney, C. (1996). Mitigation and the study of lives: on the roots of violent criminality and the nature of capital justice. In: J. R. Acker, R. M. Bohm, \& C. S. Lanier (Eds.), America's experiment with capital punishment (pp. 351- 384). Durham, NC: Carolina Academic Press.

Johnson, A. (1999). Quiet death ends years of debate. The Columbus Dispatch 2/21/99 p. 6D. Retrieved from LEXIS-NEXIS on-line database General News section on 6/22/99.

Kleck, G. (1981). Racial discrimination in criminal sentencing: a critical evaluation of the evidence with additional evidence on the death penalty. American Sociological Review, 46, 783-805.

Leonard, L. (1993). New law permits execution by lethal injection. The Columbus Dispatch, p. 6D. Retrieved on 6/24/99 from LEXIS-NEXIS General News Topics online database.

Magnum, C. S. (1940). The legal status of the Negro. Chapel Hill: University of North Carolina Press.

Maxfield, M. (1989). Circumstances in supplemental homicide reports: variety and validity. Criminology, 27, 671- 695.

Ohio Department of Rehabilitation and Correction (1999). Capital punishment in Ohio. Available at: www.drc.state. oh.us/web/capital.htm. (Retrieved March 13, 1999 from O.R.D.C. website).

O.R.C. 2929.022 (1999). In: L. R. Katz, \& P. C. Giannelli (Eds.), Ohio Criminal Justice (p. 468). Cleveland: WestGroup.

O.R.C. 2929.023 (1999). In: L. R. Katz, \& P. C. Giannelli (Eds.), Ohio Criminal Justice (p. 469). Cleveland: WestGroup. 
O.R.C. 2929.03 (1999). In: L. R. Katz, \& P. C. Giannelli (Eds.), Ohio Criminal Justice (pp. 469-471). Cleveland: WestGroup.

O.R.C. 2929.03 [D] [1] (1999). In: L. R. Katz, \& P. C. Giannelli (Eds.), Ohio Criminal Justice (p. 470). Cleveland: WestGroup.

O.R.C. 2929.04 (1999). In: L. R. Katz, \& P. C. Giannelli (Eds.), Ohio Criminal Justice (pp. 471 - 472). Cleveland: WestGroup.

Peterson, R., \& Bailey, W. (1991). Felony murder and capital punishment: an examination of the deterrence question. Criminology, 29, 367- 395.

Radelet, M. L. (1981). Racial characteristics and the imposition of the death penalty. American Sociological Review, 46, 918- 927.

Radelet, M. L., \& Pierce, G. L. (1991). Choosing who will die: race and the death penalty in Florida. Florida Law Review, 43, 1 - 34.

Riedel, M., \& Rinehart, T. (1996). Murder clearances and missing data. Journal of Crime and Justice, 19, 83- 102.

Snell, T. L. (1997). Capital punishment 1996. Washington: Bureau of Justice Statistics/U.S. Department of Justice (NCJ 167031).

Sorensen, J. R., \& Wallace, D. H. (1995). Capital punishment in Missouri: examining the issues of racial disparity. Behavioral Sciences and the Law, 13, 61- 80.

Steiker, C. S., \& Steiker, J. M. (1998). Judicial developments in capital punishment law. In: J. R. Acker, R. M. Bohm, \& C. S. Lanier (Eds.), America's experiment with capital punishment (pp. 47- 76). Durham, NC: Carolina Academic Press.

Thomson, E. (1997). Discrimination and the death penalty in Arizona. Criminal Justice Review, 22, 65- 76.

Vandiver, M. (1993). The quality of mercy: race and clemency in Florida death penalty cases, 1924-1966. University of Richmond Law Review, 27, 315-343.

Vito, G. F., \& Keil, T. J. (1988). Capital sentencing in Kentucky: an analysis of the factors influencing decision making in the post-Gregg period. Journal of Criminal Law and Criminology, 79, 483- 503.

Wolfgang, M., Kelly, A., \& Nolde, H. (1962). Comparison of the executed and the commuted among admissions to death row. Journal of Criminal Law, Criminology, and Police Science, 53, 301. 
Cases Cited

Furman v. Georgia, 408 U.S. 238 (1972).

Gregg v. Georgia, 428 U.S. 153 (1976).

Lockett v. Ohio, 438 U.S. 586 (1978).

McCleskey v. Kemp, 478 U.S. 1019 (1987).

State v. Carter, 72 Ohio St. 3d 545; 651 N.E. 2d 965 (1995).

State v. Dickerson, 45 Ohio St. 3d 206; 543 N.E. 2d 1250 (1989).

State v. Jenkins, 15 Ohio St. 3d 164; 473 N.E. 2d 264 (1984).

State v. Keene, 81 Ohio St. 3d 646; 693 N.E. 2d 246 (1998).

State v. Sowell, 39 Ohio St. 3d 322; 530 N.E. 2d 1294 (1988).

State v. Steffen, 31 Ohio St. 3d 111; 509 N.E. 2d 383 (1987). 